\title{
Investigation of a killer strain of Zygosaccharomyces bailii
}

\author{
Ferdinand Radler, ${ }^{*}$ Susanne Herzberger, Inge Schönig and Petra Schwarz \\ Institut für Mikrobiologie und Weinforschung der Johannes Gutenberg-Universität, Postfach 3980, D-6500 Mainz, \\ Germany
}

(Received 29 July 1992; revised 16 October 1992; accepted 19 November 1992)

\begin{abstract}
The yeast Zygosaccharomyces bailii strain 412 was found to liberate a killer toxin (KT412) lethal to sensitive strains of Saccharomyces cerevisiae and Candida glabrata. Culture supernatants of the killer strain were concentrated by ultrafiltration and the extracellular protein was purified by gel filtration and ion-exchange chromatography. Gel filtration and SDS-PAGE of the electrophoretically homogeneous killer protein indicated an apparent molecular mass of $10 \mathrm{kDa}$. The killer toxin KT412 is probably not glycosylated since it did not show any detectable carbohydrate structures. KT412 was bound to sensitive but not to resistant yeast cells. The mannan, and not the glucan, fraction of the cell wall of the sensitive yeast was the primary target for the killer toxin binding. The killer strain $Z$. bailii 412 contained three double-stranded RNA plasmids of $1.9,2.9$ and $4.0 \mathrm{~kb}$. Curing by cycloheximide resulted in the concomitant loss of killer activity and the $1.9 \mathrm{~kb}$ dsRNA species that is therefore regarded as equivalent to the killer-toxin-coding M-plasmids of $S$. cerevisiae.
\end{abstract}

\section{Introduction}

The phenomenon of killer activity is frequent among yeasts. Occasionally almost half of new yeast isolates are killer strains (Radler et al., 1985), and we have observed that many yeast strains with known genetic markers are killer strains. Killer strains produce protein or glycoprotein killer toxins that kill sensitive yeast strains. This phenomenon has been thoroughly reviewed (Bussey, 1981; Tipper \& Bostian, 1984; Wickner, 1986; Young, 1987). Bevan \& Makower (1963) first described killer strains of Saccharomyces cerevisiae. Thereafter, killer yeasts were observed in various yeast genera (Young \& Philliskirk, 1977; Young \& Yagiu, 1978; Middelbeek et al., 1980; Radler et al., 1985).

Different types of killer-toxin-producing yeast strains have been described within the genus Saccharomyces. In this genus, expression of the killer phenotype depends on the presence of two double-stranded RNA plasmids (called L- and M-plasmids). In Kluyveromyces lactis, two DNA plasmids determine the killer activity. Since dsRNA or dsDNA plasmids were only observed in some strains of the genera Saccharomyces, Kluyveromyces and

\footnotetext{
*Author for correspondence. Tel. 496131392662 ; fax 496131 392695.

Abbreviations: aU, arbitrary unit; ds, double-stranded; PAS, periodic acid/Schiff.
}

Pichia, it was assumed that the killer toxins of other genera are encoded by chromosomal genes (Young, 1987). This is not so, for it was later found that the killer phenotype of Hanseniaspora uvarum depended on dsRNA plasmids as well (Zorg et al., 1988).

When screening yeast strains of the genus Zygosaccharomyces for killer activity, one strain (Zygosaccharomyces bailii 412) was found that showed a wide range of activity and contained dsRNA plasmids. As the killing spectrum of this strain was different from all killer toxins known so far, it was of interest to investigate this killer yeast by characterizing its killer toxin and determining the possible role of its RNA plasmids.

\section{Methods}

Micro-organisms, culture media, and determination of killer activity. The yeast strains used were from the collection of this institute. Zygosaccharomyces bailii 412 was originally obtained from Dr F. E. M. J. Sand, Bussum, the Netherlands; the various killer yeasts of the $\mathrm{K}$-series and the sensitive strain Saccharomyces cerevisiae 452 ( = NCYC 1006) were from Dr T. W. Young, Birmingham, UK.

Media, methods of cultivation and determination of killer activity have been described previously (Pfeiffer \& Radler, 1984; Radler \& Schmitt, 1987). YEP agar contained glucose $(2 \%, w / v)$, peptone $(2 \%$, $\mathrm{w} / \mathrm{v})$, yeast extract $(1 \%, \mathrm{w} / \mathrm{v})$, agar $(1.2 \%, \mathrm{w} / \mathrm{v})$, and the $\mathrm{pH}$ was adjusted with potassium dihydrogen phosphate. YEPC medium was YEP with sodium citrate $(1.92 \%, w / v)$ but without agar. The killer toxin is expressed in arbitrary units (aU). Based on the well test method (agar diffusion test), $10 \mathrm{aU}$ correspond to the amount of killer toxin that causes an inhibition zone of $10 \mathrm{~mm}(20 \mathrm{~mm}$ measured diameter of 
inhibition zone minus $10 \mathrm{~mm}$ diameter of the well) in the lawn of the sensitive strain $S$. cerevisiae 452 .

Production and purification of the killer toxin (KT412) of Z. bailii. $Z$. bailii 412 was cultivated in $2 \times 5000 \mathrm{ml}$ synthetic B-medium (Pfeiffer \& Radler, 1982) that was adjusted to $\mathrm{pH} 4.0$, with the addition of $15 \%$ (v/v) glycerol, at $20^{\circ} \mathrm{C}$ and with gentle stirring, for $4 \mathrm{~d}$. After removal of the cells by centrifugation the culture liquid was concentrated by ultrafiltration, first with a Sartorius membrane to $400 \mathrm{ml}$, then with an Omega membrane (Filtron) to about $20 \mathrm{ml}$. The cut-off of both membranes was $10 \mathrm{kDa}$. After centrifugation, the concentrate was dialysed in Visking tubing type 36/32, $27 \mathrm{~mm}$ diam. (Roth), against $2 \times 2000 \mathrm{ml} 20 \mathrm{~mm}$-malonate/phosphate buffer, pH $2 \cdot 7$, with the addition of $15 \%(\mathrm{v} / \mathrm{v})$ glycerol and $4 \mathrm{M}$-urea, for $2 \times 12 \mathrm{~h}$. Before storage, the dialysate was filtered through a Millex-GV-filter (Millipore, $0 \cdot 22 \mu \mathrm{m})$. Dialysate $(5 \mathrm{ml})$ containing killer toxin was applied to a column $(1.2 \times 5 \mathrm{~cm})$ of S-Sepharose, from which the killer toxin was eluted with a linear gradient of $0-1 \mathrm{M}-\mathrm{NaCl}(180 \mathrm{ml})$ in $20 \mathrm{~mm}-$ malonate/phosphate buffer [pH 2.7; $15 \%(\mathrm{v} / \mathrm{v})$ glycerol; $4 \mathrm{M}$-urea]. Fractions of $6 \mathrm{ml}$ were collected and the killer-toxin-containing fractions (nos 15 to 19 ) were pooled and dialysed overnight against 4 litres $10 \mathrm{~mm}$-citrate/phosphate buffer $[\mathrm{pH} 3 \cdot 7 ; 15 \%(\mathrm{v} / \mathrm{v})$ glycerol] to remove the urea before lyophilization. The residue obtained after lyophilization was dissolved in a small volume of the same buffer. A sample $(200 \mu \mathrm{l})$ of this preparation was applied to a column of Superose 12 (FPLC) from which the killer toxin was eluted with $100 \mathrm{~mm}$ citrate/phosphate buffer ( $\mathrm{pH} 3.7 ; 150 \mathrm{~mm}-\mathrm{NaCl} ; 4 \mathrm{M}$-urea). The fraction size was $1 \mathrm{ml}$ and KT412 was found in fraction nos 15-17, of which fraction no. 16 was collected for further use. SDS-PAGE was performed according to Laemmli (1970), with minigels (Biometra) that were stained with the Silverstain kit for protein or with the periodic acid/Schiff (PAS) reagent according to Zacharius et al. (1969). The killer toxin $\mathrm{K}_{28}$ from $S$. cerevisiae was isolated as described previously (Schmitt \& Radler, 1987).

Isolation and detection of dsRNA plasmids. Cells of $Z$. bailii were extracted with phenol/chloroform, single-stranded RNA was removed by $\mathrm{LiCl}$ precipitation and the remaining nucleic acids were precipitated with ethanol as described by Schmitt \& Tipper (1990). For electrophoresis $1 \%(\mathrm{w} / \mathrm{v})$ agarose in TBE buffer $(0.089 \mathrm{M}$-Tris/boric acid, pH 8.3, 0.0025 M-Na $\mathrm{N}_{2}$ EDTA) was used as described by Maniatis et al. (1982).

Adsorption of killer toxin to cells, cell walls and cell wall polysaccharides. The experiments with the killer toxin of $Z$. bailii were performed as described by Schmitt \& Radler $(1987,1988)$ for $S$. cerevisiae. Cell wall preparations of strains of $S$. cerevisiae were prepared as described previously (Radler \& Schmitt, 1987). For the preparation of mannan, the yeast cells were extracted with $\mathrm{NaOH}(3 \%$, $\mathrm{w} / \mathrm{v}$, at $75^{\circ} \mathrm{C}$ for $2 \mathrm{~h}$ ), and the mannan-copper complex was precipitated by adding Fehling's solution. The mannan was dissolved in $3 \mathrm{M}-\mathrm{HCl}$ and then precipitated with methanol/acetic acid $(8: 1, \mathrm{v} / \mathrm{v})$. The glucan fractions were extracted from the alkali-insoluble residue with $0.5 \mathrm{M}$-acetic acid at $90^{\circ} \mathrm{C}$.

\section{Results}

Killer activity of Zygosaccharomyces bailii

When 40 strains of the genus Zygosaccharomyces were screened for killer activity using Saccharomyces cerevisiae 467 as the sensitive tester strain only strain 412 showed a distinct killer activity determined by the usual agar diffusion test. In cross-reactions with 21 killer yeasts of eight different genera and 20 non-killer strains of the genera Saccharomyces, Candida, Kluyveromyces and Saccharomycodes, the killer yeasts $S$. cerevisiae $466(\mathrm{~K} 1)$, Candida glabrata 453 (K4), Kluyveromyces marxianus (K6) and Hanseniaspora uvarum 470, and the non-killers Candida krusei 15, and 6 out of 10 tested S. cerevisiae strains, were sensitive to the killer toxin of $Z$. bailii. The new killer strain of $Z$. bailii 412 was inhibited only by a newly isolated killer strain of Torulaspora delbrueckii $3 / 40$. This pattern of cross-reactivity was different from that of all other available killer yeasts. Therefore, the killer activity of $Z$. bailii 412 was investigated further, as (to our knowledge) no killer strains of this genus have hitherto been described.

\section{Characteristics of the killer toxin (KT412) of Z. bailii 412}

We first demonstrated that the killer activity of $Z$. bailii 412 is caused by a protein (killer toxin), which will be designated KT412. The killer activity was destroyed (76-97\%) by incubation with proteinase $\mathrm{K}$ and protease type XIII (Sigma). Other proteinases, such as pronase E and trypsin, had little effect (less than $15 \%$ inactivation after $24-48 \mathrm{~h}$ ) on the activity of the native killer toxin. Yeast killer toxins are usually temperature- and $\mathrm{pH}$ sensitive. The killer toxin of $Z$. bailii 412 is no exception. When kept at $37^{\circ} \mathrm{C}$ for $3 \mathrm{~h}$ at $\mathrm{pH} 3 \cdot 7$, more than half of the activity was lost; at $50{ }^{\circ} \mathrm{C}$ about $90 \%$ of the activity was lost within $1 \mathrm{~h}$. The killer toxin was most stable at pH 3 when kept at $4{ }^{\circ} \mathrm{C}$ for $24 \mathrm{~h}$. Less than half of the activity was lost at $\mathrm{pH} 2$ or $\mathrm{pH} 6$; above $\mathrm{pH} 6$ the inactivation increased ( $80 \%$ loss) significantly, and at pH 9 all activity was destroyed completely.

The killer toxin was precipitated from the culture fluid with $50 \%(\mathrm{v} / \mathrm{v})$ ethanol. The activity could be concentrated by lyophilization, but ultrafiltration with a $10 \mathrm{kDa}$ cut-off membrane was the preferred method. It was shown by isoelectric focusing that the isoelectric point of the killer toxin of $Z$. bailii was approximately pH 4.1. KT412 was found in the culture fluid. Cell extracts of washed cells of $Z$. bailii 412 contained only about $0.2 \%$ of the killer activity of the culture fluid.

\section{Purification of the killer toxin KT412}

The synthetic B-medium was used to facilitate the isolation of killer toxin. This avoided high molecular mass compounds in the culture medium. Glycerol was found to stabilize KT412, therefore $15 \%$ (v/v) glycerol was added to the medium prior to sterilization. After the cells had been removed by centrifugation, KT412 in the culture fluid was concentrated about 100 -fold by ultrafiltration. This concentrate was dialysed, and subsequently resolved by cation-exchange chromatography 
Table 1. Purification of the extracellular killer toxin, KT412, of Z. bailii 412

\begin{tabular}{lcccccc}
\hline \hline Purification step & $\begin{array}{c}\text { Protein } \\
(\mathrm{mg})\end{array}$ & $\begin{array}{c}\text { Vol. } \\
(\mathrm{ml})\end{array}$ & $\begin{array}{c}10^{-6} \times \text { Total } \\
\text { activity (aU) }\end{array}$ & $\begin{array}{c}10^{-3} \times \text { Specific } \\
\text { activity } \\
(\mathrm{aU} \mathrm{mg})\end{array}$ & $\begin{array}{c}\text { Factor } \\
\text { Yield } \\
(\% \text { activity) }\end{array}$ \\
\hline $\begin{array}{l}\text { Culture fluid after } \\
\text { ultrafiltration and } \\
\text { dialysis }\end{array}$ & 127 & 20 & $2 \cdot 8$ & 22 & 1 & 100 \\
S-Sepharose & 18 & 11 & $2 \cdot 7$ & & & 96 \\
Superose $\mathrm{TM}_{12}$ & 2 & 1 & 1.8 & 880 & 40 & 64 \\
\hline \hline
\end{tabular}

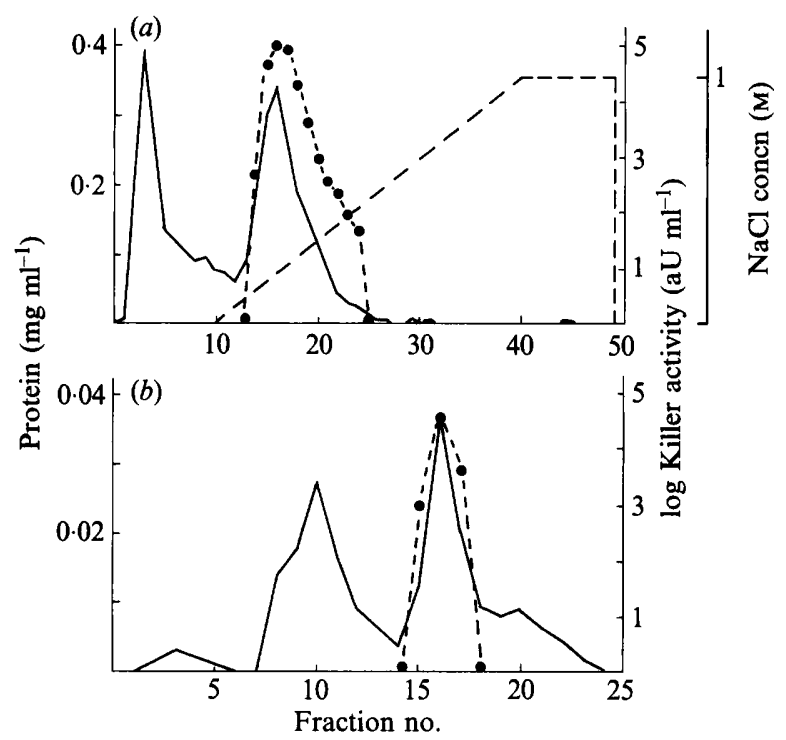

Fig. 1. Purification of the killer toxin of $Z$. bailii 412 by cation-exchange chromatography $(a)$ and gel filtration $(b)$. 9 , Killer toxin activity; -_, protein; ---, $\mathrm{NaCl}$ gradient.

on S-Sepharose followed by gel filtration on Superose $\mathrm{TM}_{12}$. The purification procedure is summarized in Table 1 and examples of column chromatograms are depicted in Fig. 1.

When the most active fraction obtained after gel filtration was subjected to SDS-PAGE, one protein band with a relative molecular mass of about $10 \mathrm{kDa}$ was detected. The two bands in the range $60-70 \mathrm{kDa}$ are due to an artefact and were probably caused by impurities in the mercaptoethanol preparation used. The SDS-PAGE of the preparations of KT412 during the course of purification is shown in Fig. 2. The apparent molecular mass of KT412 was confirmed by gel filtration on Superose $\mathrm{TM}_{12}$. The killer toxin eluted between cytochrome $c$ and aprotinin, indicating an apparent molecular mass of about $10 \mathrm{kDa}$.

KT412 could not be stained with PAS; this means that no carbohydrate moiety could be detected. The wellknown glycoprotein toxin $\mathrm{K}_{28}$ of $S$. cerevisiae gave a distinct signal. $\mathrm{K}_{28}$ contains about 10 mannose residues per molecule (Schmitt \& Pfeiffer, 1990). In accordance

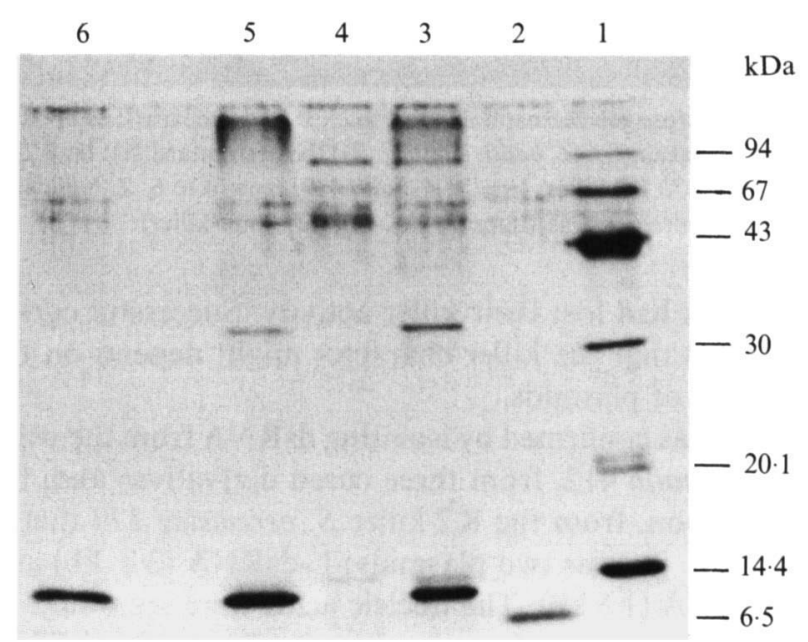

Fig. 2. SDS-PAGE of preparations during the purification of KT412. Lane 1, low-molecular-mass markers; lane 2, aprotinin; lane 3, concentrated culture liquid of $Z$. bailii; lane 4, preparation after cationexchange chromatography, fraction eluted before killer toxin activity; lane 5, KT412 after cation-exchange chromatography; lane 6, purified KT412 after gel filtration. Five micrograms of protein were applied to lanes 3 to 6 .

with this observation KT412 did not bind to ConAconjugated Sepharose. This can be regarded as further evidence that KT412 is not glycosylated.

\section{Curing of the killer strain and investigation of its dsRNA plasmids}

Killer yeasts can be cured of their killer phenotype by cultivation at elevated temperatures, or by treatment with cycloheximide or 5-fluorouracil (Fink \& Styles, 1972; Mitchell et al., 1973; Wickner, 1974; Zorg et al., 1988). At first the attempts to cure $Z$. bailii 412 by growing at $35^{\circ} \mathrm{C}$, or treatment with ethidium bromide, cycloheximide, AZT, ( $3^{\prime}$-azido-3'-deoxythymidine), acridine orange or 5-fluorouracil were not successful. Then it was observed that in the presence of $10 \mathrm{mg}$ cycloheximide $1^{-1}$ tiny colonies developed after about a week on YEP agar. When these colonies were propagated on YEP and then subcultured again on cycloheximidecontaining YEP agar, it was found that about $3 \%$ of the 


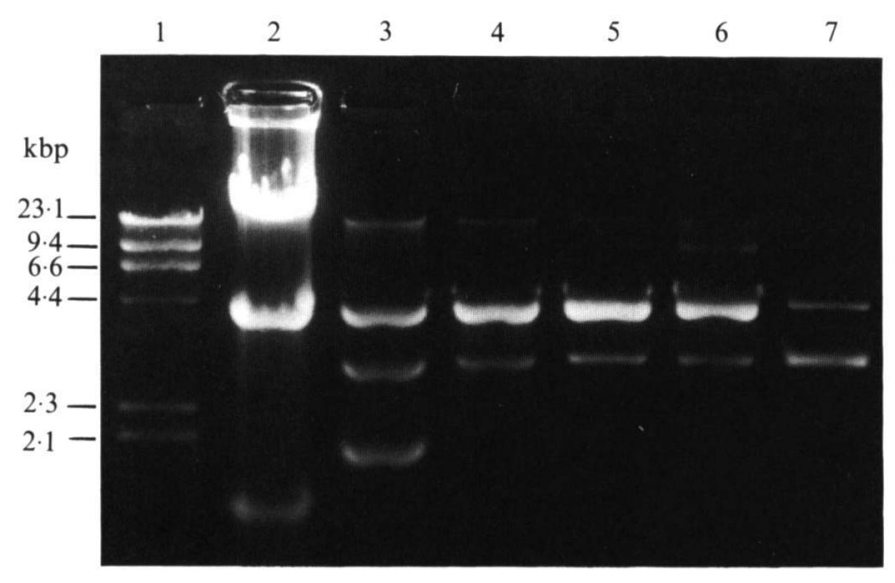

Fig. 3. Agarose gel electrophoresis of nucleic acid preparations of cured and killer strains of $Z$. bailii. Lane 1, $\lambda$-DNA (standard II); lane 2, $S$. cerevisiae 379 K2-killer; lane 3, Z. bailii 412 ; lanes 4 to $6, Z$. bailii $412 \mathrm{c}$ (different cured strains); lane 7, Z. bailii 427 (non-killer).

survivors had lost their killer activity. Successful curing indicated that the killer character might depend on the presence of plasmids.

This was confirmed by isolating dsRNA from the wildtype $Z$. bailii 412 , from three cured derivatives and, for comparison, from the K2-killer $S$. cerevisiae 379 that is known to possess two plasmids: L-dsRNA $(3.8 \mathrm{~kb})$ and M-dsRNA $(1.5 \mathrm{~kb})$. The nucleic acids were separated by agarose gel electrophoresis. (Fig. 3). L- and M-dsRNA of $S$. cerevisiae are clearly visible. The wild-type strain of $Z$. bailii 412 contained three plasmids. By comparison with the $E c o \mathrm{RI} / H$ indIII fragments of $\lambda$ DNA the size of those plasmids was $4.0,2.9$ and $1.9 \mathrm{~kb}$. When the extracts were treated with RNAase under low-salt conditions $(120 \mu \mathrm{g}$ RNAase in $600 \mu \mathrm{l}$ of a solution of $10 \mathrm{~mm}$-Tris + $10 \mathrm{mM}-\mathrm{MgCl}_{2}$ ) or under high-salt conditions (additional $0.6 \mathrm{M}-\mathrm{NaCl}$ ) at $37^{\circ} \mathrm{C}$ for 1,2 and $3 \mathrm{~h}$ the bands disappeared only under the low-salt conditions, indicating that they consisted of dsRNA.

The cured strains of $Z$. bailii that had lost the killer activity and the non-killer strain $Z$. bailii 427 showed only two bands $(4.0 \mathrm{~kb}$ and $2.9 \mathrm{~kb})$. In the extracts of the cured strains the amount of RNA of the $4.0 \mathrm{~kb}$ band increased. This increase of L-dsRNA copy number in the absence of $\mathbf{M}$ is a well-known phenomenon in cured strains of S. cerevisiae (Wickner, 1986).

\section{Action and adsorption of KT412}

The inhibition zones that appear in the lawn of the sensitive yeast ( $S$. cerevisiae 452 ) around the wells in the agar diffusion test can be due to a microbicidal or a static action of the inhibiting agent. When killer toxin KT412 was added to growing yeast cells in YEPD medium, the microbicidal action was obvious (Fig. 4). Depending on the concentration of the killer toxin and on the sensitivity

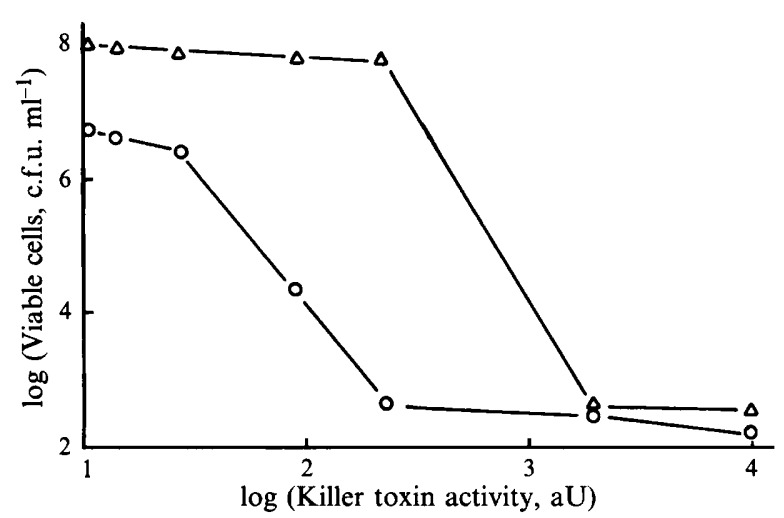

Fig. 4. Influence of different concentrations of KT412 on the viability of two sensitive strains of $S$. cerevisiae $(\triangle, S$. cerevisiae $381 ; \bigcirc, S$. cerevisiae 452).
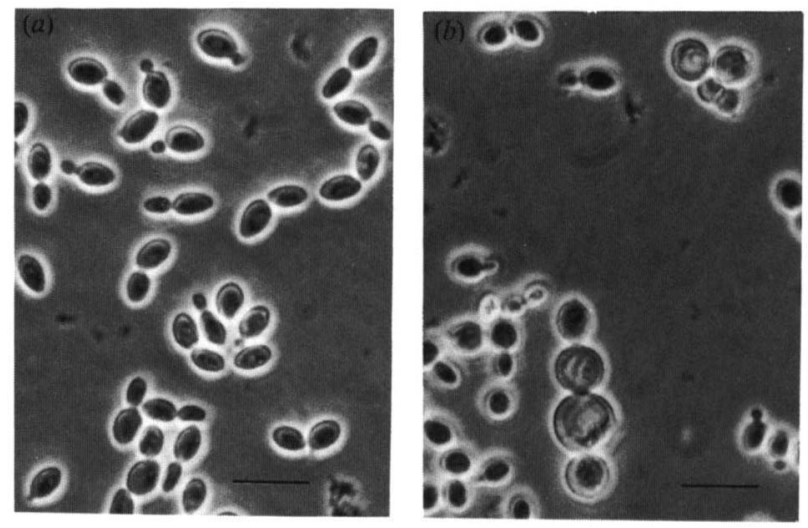

Fig. 5. Phase-contrast micrographs showing the effect of KT412 on the morphology of the sensitive strain $S$. cerevisiae 452. (a) Control; (b) with $27 \mathrm{aU} \mathrm{KT} 412 \mathrm{ml}^{-1}$. Cells were incubated for $24 \mathrm{~h}$ at $20^{\circ} \mathrm{C}$ in YEPD medium $\mathrm{pH} 4 \cdot 0$, with gentle shaking. Bars, $20 \mu \mathrm{m}$.

of the tester strain, not only was growth inhibited but also cell viability decreased from about $10^{6}$ to $10^{2}$ cells $\mathrm{ml}^{-1}$ within $24 \mathrm{~h}$.

The mode of action of KT412 on sensitive cells is unknown. The killer toxin $\mathrm{K} 1$ affects the proton gradient of the cell membrane and acts as an ionophore; thus low molecular mass solutes leak out of the cells, which finally die (Bussey, 1981). KT412 changed the appearance of a sensitive yeast at high concentrations. At the inhibitory but not lethal concentration of $27 \mathrm{aU}$ about $1 \%$ giant cells were observed (Fig. 5). When treated with SDS, these round giant cells did not lyse, therefore it can be assumed that they are not spheroplasts lacking an intact cell wall.

According to the two-step model proposed for the action of killer toxin $\mathrm{K} 1$, the first step is the adsorption of the killer toxin to the cell wall (Bussey, 1981). Therefore, the adsorption of KT412 by yeast cells was tested. The killer toxin was added to different amounts of cells of the sensitive strain $S$. cerevisiae 452 , the resistant strain $S$. cerevisiae 496 and the intermediate strain $S$. 


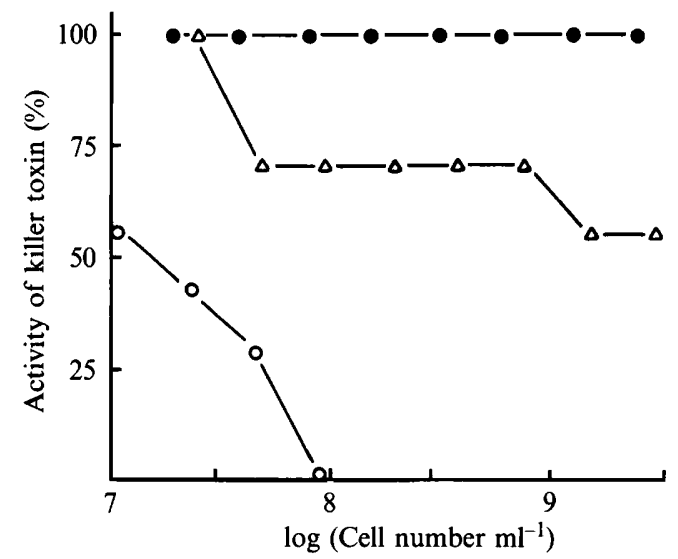

Fig. 6. Adsorption of KT412 to resistant (O, strain 496) and sensitive strains $(\triangle, 381 ; O, 452)$ of $S$. cerevisiae $(100 \%$ residual activity corresponds to $155 \mathrm{aU} \mathrm{KT} 412 \mathrm{ml}^{-1}$ after $1 \mathrm{~h}$ incubation at $4{ }^{\circ} \mathrm{C}$ in the absence of cells).

Table 2. Inactivation of KT412 by adsorption to the cell wall polysaccharides mannan and glucan of $S$. cerevisiae 452 , and pustulan and laminarin

The sensitive strain $S$. cerevisiae $452\left(5.4 \times 10^{5}\right.$ c.f.u. $)$ was incubated with $90 \mathrm{aU} \mathrm{KT} 412$ in $3 \mathrm{ml} \mathrm{YEPC}$ medium, pH 4, for $24 \mathrm{~h}$ at $20^{\circ} \mathrm{C}$ with gentle shaking.

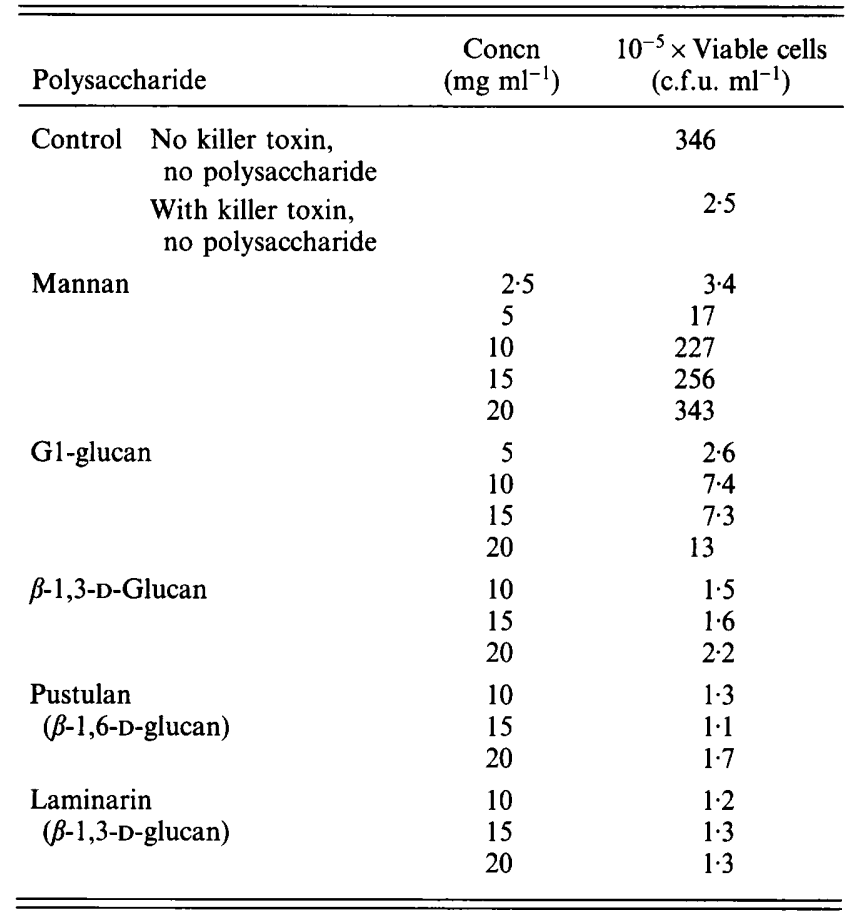

cerevisiae 381. After incubation for $1 \mathrm{~h}$ at $4{ }^{\circ} \mathrm{C}$ no killer toxin had been adsorbed by the resistant strain, whereas $10^{8}$ cells ml $^{-1}$ of the sensitive strain had completely adsorbed KT412. Only some of the killer toxin was removed by the less sensitive strain $S$. cerevisiae 381 (Fig. 6). Similar results were obtained with isolated yeast cell walls (data not shown).
The main components of the yeast cell wall are glucans and mannoproteins. Hutchins \& Bussey (1983) observed that the killer toxin $\mathrm{K} 1$ was adsorbed by a $\beta$-1,6-glucan, whereas a $180 \mathrm{kDa}$ mannoprotein was identified as the primary receptor for the $\mathrm{K}_{28}$ killer toxin of $S$. cerevisiae (Schmitt \& Radler, 1987, 1988). To determine the primary acceptor of the cell wall for KT412, several polysaccharides and cell wall preparations were used in the adsorption test. When $0.54 \times 10^{6}$ cells of the sensitive yeast $S$. cerevisiae 452 were exposed to $89 \mathrm{aU}$ of KT412, about $50 \%$ of the cells were killed within $24 \mathrm{~h}$. In the absence of killer toxin, the cells grew to a total of $34.6 \times 10^{6}$ cells (Table 2 ). Of the polysaccharides tested, only the crude mannan fraction prevented the action of the killer toxin. Therefore, it was concluded that the primary binding sites for killer toxin KT412 are located within the mannan and not within the glucan fraction of the yeast cell wall.

\section{Discussion}

Since the first observation of killer toxins within the species Saccharomyces cerevisiae (Bevan \& Makower, 1963), this phenomenon has been observed in many yeast genera. The first killer yeast was designated $\mathrm{K} 1$ when it was realized that another strain, called $\mathrm{K} 2$, showed no cross immunity. In fact, these two types killed each other. Due to similar cross-reactions, the first more general attempt to classify killer yeasts of seven genera was made by Young \& Yagiu (1978), who assigned arbitrary numbers to killer yeasts. The killer strain of Zygosaccharomyces bailii 412 described in this paper differs from the killer yeasts that are known so far. Although forming an active killer toxin, the spectrum of activity is rather small, being restricted to certain strains of $S$. cerevisiae and Candida glabrata. More detailed studies have revealed that KT412 is active against most strains of Zygosaccharomyces (S. Kaiser, personal communication).

Although the spectrum of activity of killer yeasts is easily determined when suitable tester strains are available, it seems more rational to distinguish killer yeasts according to the characteristics of the killer toxins that they produce. All known killer toxins are acidic proteins, with an isoelectric point of about $\mathrm{pH} 4$. Most killer toxins have a molecular mass in the range $10-20 \mathrm{kDa}$. The only exception is the killer toxin of Kluyveromyces lactis, which consists of three polypeptide subunits (27.5, 30 , and $99 \mathrm{kDa})$. The existence of subunits $\left(\mathrm{K}_{1}\right.$ or killer toxin of Kluyveromyces) is not the rule. One main difference may be that some killer toxins, such as $\mathrm{K}_{2}, \mathrm{~K}_{28}$ or the killer toxin of Kluyveromyces, contain carbohydrate residues; the others are obviously unglycosylated polypeptides. Whereas the killer toxin $\mathrm{K}_{28}$ 
contains about 10 mannose residues, no carbohydrate was detected in KT412 with PAS or by adsorption to ConA-Sepharose. However, neither method is sufficiently sensitive or specific to detect a very small amount of mannose.

The characteristics of the different killer toxins depend on the information stored in the nucleic acid and on post-translational modification, i.e. glycosylation. The information for the killer toxin of $K$. lactis is encoded by two DNA plasmids. The killer toxins $\mathrm{K}_{1}, \mathrm{~K}_{2}$ and $\mathrm{K}_{28}$ of $S$. cerevisiae are encoded by distinct dsRNAs that are encapsidated by protein capsomers. The killer toxins of Hanseniaspora uvarum (Zorg et al., 1988 ) and $Z$. bailii 412 belong to this group. Z. bailii 412 contains three dsRNA plasmids. It is assumed that the largest $(4.0 \mathrm{~kb})$ and the smallest $(1.9 \mathrm{~kb})$ correspond to the L- and M-plasmids of $S$. cerevisiae. This was shown by curing, as strains of $Z$. bailii without the M-plasmid lost killer activity. Furthermore, it has been possible to transfer the M-plasmid of $Z$. bailii 412 to a strain of $S$. cerevisiae by transfection, thereby converting this strain to a killer strain (M. J. Schmitt, personal communication). The significance of the third dsRNA $(2.9 \mathrm{~kb})$ is unknown; it is also protein encapsidated (F. Neuhausen, personal communication) and will be called Z-plasmid ( $\mathrm{Z}$ for Zygosaccharomyces).

Conclusive evidence exists that the killer toxin $K_{1}$ acts on the membrane of sensitive cells (de la Peña et al., 1981; Martinac et al., 1990). However, it is doubtful that all killer toxins have the same mode of action; for example, $\mathrm{K}_{28}$ of $S$. cerevisiae has been shown to cause an early inhibition of DNA synthesis (Schmitt et al., 1989). With regard to the primary receptor of the cell wall, the killer toxins show different affinities. The killer toxins $\mathbf{K}_{1}$ and $\mathrm{K}_{2}$ of $S$. cerevisiae and that of $H$. uvarum are adsorbed by glucans, whereas killer toxin $\mathrm{K}_{28}$ and the killer toxins of Debaryomyces hansenii (S. Kilian, personal communication) and Z. bailii (this paper) are adsorbed by mannans of the yeast cell wall. As the latter two killer toxins are non-glycosylated polypeptides, the presence of mannose residues is obviously not essential for efficient binding to the yeast cell wall.

\section{References}

Bevan, E. A. \& Makower, M. (1963). The physiological basis of the killer character in yeast. Proceedings of the XI International Congress of Genetics 1, 202-203.

Bussey, H. (1981). Physiology of killer factor in yeast. Advances in Microbial Physiology 22, 93-122.

Bussey, H., Boone, C., Zhu, H., Vernet, T., Whiteway, M. \& Thomas, D. Y. (1990). Genetic and molecular approaches to synthesis and action of yeast killer toxin. Experientia 46, 193-200.

Fink, G. R. \& STYles, C. A. (1972). Curing of a killer factor in Saccharomyces cerevisiae. Proceedings of the National Academy of Science of the United States of America 69, 2846-2849.
Hutchins, K. A. \& BusSeY, H. (1983). Cell wall receptor for yeast killer toxin: involvement of $(1 \rightarrow 6)-\beta$-D-glucan. Journal of Bacteriology 154 , 161-168.

LAEMMLI, U. K. (1970). Cleavage of structural proteins during the assembly of the head of bacteriophage T4. Nature, London 277, 680-685.

Maniatis, T., Fritsch, E. F. \& Sambrook, J. (1982). Molecular Cloning: a Laboratory Manual. Cold Spring Harbor, NY: Cold Spring Harbor Laboratory.

Martinac, B., Zhu, H., Kubalski, A., Zhou, X., Culbertson, M., BuSSEY, H. \& KUNG, C. (1990). Yeast K1 killer toxin forms ion channels in sensitive yeast spheroplasts and in artificial liposomes. Cell Biology 87, 6228-6232.

Middelbeek, E. J., Von de LaAR, H. H. A. M., Hermans, J. M. H., Stumm, G. \& Vogels, G. D. (1980). Physiological conditions affecting the stability of Saccharomyces cerevisiae killer toxin and energy requirement for toxin action. Antonie van Leeuwenhoek 46, 483-497.

Mitchell, D. J., Bevan, E. A. \& Herring, A. J. (1973). The correlation between dsRNA in yeast and the killer character. Heredity 31, 133-134.

Pfeiffer, P. \& Radler, F. (1982). Purification and characterization of extracellular and intracellular killer toxin of Saccharomyces cerevisiae strain 28. Journal of General Microbiology 128, 2699-2706.

Pfeiffer, P. \& RADLER, F. (1984). Comparison of the killer toxin of several yeasts and the purification of a toxin of type $\mathrm{K}_{2}$. Archives of Microbiology 137, 357-361.

RADLER, F. \& SchMITT, M. J. (1987). Killer toxins of yeasts: inhibitors of fermentation and their adsorption. Journal of Food Protection 50, 234-238.

Radler, F., Pfeiffer, P. \& Dennert, M. (1985). Killer toxins in new isolates of the yeasts Hanseniaspora uvarum and Pichia kluyveri. FEMS Microbiology Letters 29, 269-272.

SChmitT, M. J. \& PFeiffer, P. C. (1990). Immunochemical analysis of the carbohydrate moiety of yeast killer toxin $\mathrm{K}_{28}$. Antonie van Leeuwenhoek 58, 277-282.

SCHMITT, M. \& RADLER, F. (1987). Mannoprotein of the yeast cell wall as primary receptor for the killer toxin of Saccharomyces cerevisiae strain 28. Journal of General Microbiology 133, 3347-3354.

SCHMITT, M. \& RADLER, F. (1988). Molecular structure of the cell wall receptor for killer toxin KT28 in Saccharomyces cerevisiae. Journal of Bacteriology 170, 2192-2196.

SCHMITT, M. J. \& TIPPER, D. J. (1990). $\mathrm{K}_{28}$, a unique double-stranded RNA killer virus of Saccharomyces cerevisiae. Molecular and Cellular Biology 10, 4807-4815.

SCHMitT, M. J., BRendel, M., Schwarz, R. \& RadLeR, F. (1989). Inhibition of DNA synthesis in Saccharomyces cerevisiae by yeast killer toxin KT28. Journal of General Microbiology 135, 1529-1535.

TipPer, D. J. \& Bostian, K. A. (1984). Double-stranded ribonucleic acid killer systems in yeasts. Microbiological Reviews 48, 125-156.

WICKNER, R. B. (1974). Chromosomal and nonchromosomal mutations affecting the killer character of Saccharomyces cerevisiae. Genetics 76, 423-432.

WICKNER, R. B. (1986). Double-stranded RNA replication in yeast: the killer system. Annual Reviews in Biochemistry 55, 373-395.

Young, T. W. (1987). Killer yeasts. In The Yeasts, pp. 131-164. Edited by A. H. Rose \& J. S. Harrison. New York: Academic Press.

Young, T. W. \& Philliskirk, G. (1977). The production of a yeast killer factor in the chemostat and the effects of killer yeasts in mixed continuous culture with a sensitive strain. Journal of Applied Bacteriology 43, 425-436.

Young, T. W. \& YAGIU, M. (1978). A comparison of the killer character in different yeasts and its classification. Antonie van Leeuwenhoek 44, 59-77.

Zacharius, R. M., Zell, T. E., Morrison, J. H. \& Woodlock, J. J. (1969). Glycoprotein staining following electrophoresis on acrylamide gels. Journal of Analyical Biochemistry 30, 148-152.

ZORG, J., KiliaN, S. \& RAdLeR, F. (1988). Killer toxin producing strains of the yeasts Hanseniaspora uvarum and Pichia kluyveri. Archives of Microbiology 149, 261-267. 